\title{
Beyond the limits of the law: a Christological reading of Christopher Nolan's The Dark Knight
}

\author{
Timothy D Peters* \\ Griffith Law School, Griffith University, Gold Coast, Queensland, Australia
}

\begin{abstract}
Close readings of popular culture texts can illuminate the complexities of the narratives of law and justice that influence our legal imaginary, and provide a means for re-reading our concepts of legality. This article explores Christopher Nolan's The Dark Knight Trilogy not as a depiction of a traditional superhero who conservatively operates to supplement the legal system's goal of justice and restore the social order disrupted by criminals, villains or some other extraordinary threat, but as a non-hero who proposes a critique of justice and legality itself. It reads Batman as a Christological figure specifically because of his actions at the conclusion of the second film, The Dark Knight, in taking the blame for the murders committed by District Attorney Harvey Dent. In exploring what is an uncomfortable conclusion to the second film, I unpack how Nolan 'makes strange' the traditional superhero mythos and the narratives they tell of justice, law and legality. In this sense, The Dark Knight can be read as a Christological response to, as much as an expansion and fulfilment of, the rise of the superhero film and the superhero as a figure of the exception beyond the law.
\end{abstract}

\section{Introduction}

Following the release of The Dark Knight Rises in July 2012, the final instalment of Christopher Nolan's The Dark Knight Trilogy, ${ }^{1}$ certain critics identified Batman as a Christ figure making the 'ultimate sacrifice' to save the people of Gotham City. ${ }^{2}$ This article makes a similar claim, arguing that Batman in Nolan's trilogy can be read as a typology of Christ. However, that claim has nothing to do with any supposed 'great sacrifice' in the third film. For, as Slavoj Žižek was quick to point out, such a crass and superficial reading is patently inaccurate or, at the very least and to follow the theological reference, heretical. ${ }^{3}$ As we see in the final scenes of The Dark Knight Rises, Batman/Bruce Wayne (played by Christian Bale) did not die but can be found in Venice with Selina Kyle (the cat burglar, played by Anne Hathaway). Such a reading of Batman as Christ, then, would be more a gnostic heresy (where Christ did not actually die on the cross but escaped and lived out his life in India or Tibet ${ }^{4}$ ) rather than the orthodox Christian tradition. In addition, it situates Nolan's films purely within the superhero genre, from which he is clearly drawing, where the

\footnotetext{
*Email: t.peters@griffith.edu.au

${ }^{1}$ Consisting of Batman Begins (2005), The Dark Knight (2008) and The Dark Knight Rises (2012).

${ }^{2}$ See, for example, O’Neil (2012).

${ }^{3}$ Žižek (2012a), Žižek (2012b).

${ }^{4}$ Žižek (2012a).
} 
hero is often called upon to make a great sacrifice in order to save the city, world or universe. $^{5}$

This article proposes a counter-reading to the above in two senses. First, it seeks to read Nolan's Batman not as a traditional superhero who conservatively operates to supplement or fulfil the legal system's goal of justice and restore the social order disrupted by criminals, villains or some other extraordinary threat but as a non-hero who proposes a critique not just of an ineffective or incompetent criminal justice system (a traditional trope of the superhero genre) but of justice and legality itself. The second is to read Batman as a Christological figure not because of any great sacrifice in the third film but rather because of his morally ambiguous actions, along with Commissioner Gordon (Gary Oldman), at the end of the second film, The Dark Knight. In the final scenes of that film, Batman and Gordon conspire to promulgate a lie about Gotham City District Attorney Harvey Dent (Aaron Eckhart), with Batman taking the blame for a number of murders committed by Dent. It is by exploring what, in a number of senses, is an uncomfortable conclusion to the second film that we can see how Nolan's Batman 'makes strange' the traditional superhero mythos and the narratives that they tell of justice, law and legality. ${ }^{6}$ This approach to Nolan's film is in contrast to the general readings of The Dark Knight as promoting (or criticising) the exceptionalism associated with the politics of the 'war on terror' and the Bush administration. In this sense, The Dark Knight can be read as a Christological response to, as much as an expansion and fulfilment of, the rise of the superhero film and the superhero as a figure of the exception beyond the law.

Close readings of popular culture texts, particularly those that have significant cultural impact such as The Dark Knight, can thus illuminate the complexities of the narratives of law and justice that influence our legal imaginary, as well as provide a means for re-reading and re-encountering our concepts of legality. ${ }^{7}$ This article focuses specifically on the generic and narrative aspects of The Dark Knight, not to the exclusion of the optical aspects of the filmic medium via which the narrative is presented (lighting, camera angles, editing choices and other aspects of cinematographic style) but in terms of the way Nolan's re-telling of the Batman mythos encompasses a narrative complexity that challenges the genre in which the film sits. This narrative and generic complexity renders visible a number of the fault-lines of the superhero genre predominant both on screen and in the comic book tradition and provides insights into themes that are dominating our current legal imaginary.

The article begins by situating The Dark Knight in relation to the critical and scholarly response to it, as well as the general mythic references of the superhero genre. Drawing on the work of Carl Schmitt and Giorgio Agamben, it will outline the connections between The Dark Knight and a particular form of exceptionalism in which Batman appropriates the sovereign decision on the exception to the norm of the law. What is determinative, however, is that Nolan's Batman does not fit the

\footnotetext{
${ }^{5}$ This reading of the superhero conforms to Joseph Campbell's notion of the hero myth: see Campbell (1973); Peters (2007). See also Lawrence and Jewett (2002) on the American monomyth.

${ }^{6}$ On 'making strange' as a mode of Cultural Legal Studies, see Peters (2016).

${ }^{7}$ As such, this article follows the work of William MacNeil and others who seek to explore texts of popular culture as a means of re-reading and resignifying law and legal theory. See MacNeil (2007) and MacNeil (2012).
} 
traditional superhero mythos (fighting for truth and justice) but rather consistently fights against particular visions of justice presented by each of the villains in the film trilogy (Ra's Al Ghul, The League of Shadows, The Joker, Two-Face and Bane). Sections three and four thus analyse the forms of justice and legality that are presented by 'The Joker' (who, despite the common reading of his radical anarchy, in fact presents a conservative vision of the law as founded on violence) and Harvey 'Two-Face' Dent (who takes up the traditional superhero-vigilante critique and compresses the legal decision into an arbitrary toss of the coin). In contrast, the actions of Nolan's Batman are grounded in a form of compassion that does not seek a retributive or vigilante justice but enact a form of preventative violence founded in love. It is in this sense that section five provides a Christological reading of The Dark Knight that opens the possibility of a different grounding of law, justice and trust in the community of the city. This is a reading not taken up by The Dark Knight Rises and leaves us wondering whether what we need is not another hero-narrative (so prevalent in popular culture) but rather someone who operates specifically as a non-hero ... maybe a Dark Knight.

\section{Myths of the post-9/11 superhero: law, exceptionality and justice}

Whilst superheroes on film have a history that goes back almost as far as their first appearance in comic books, the prominence of the superhero film since the turn of the millennium is unprecedented. ${ }^{8}$ Given the tradition of superheroes being coopted to assist in the war effort, it hardly seems uncanny to note a connection between the rise of the superhero film and the post-9/11 'war on terror' environment.' However, it was Nolan's The Dark Knight that evoked the strongest reaction and identification of such connections between Hollywood and the Bush Administration era of post-9/11 politics with one critic even describing it as 'the first true, post 9/11 superhero movie'. ${ }^{10}$ Following its release in 2008, a number of critics labelled The Dark Knight a conservative film that supported and validated the tactics and strategies used by the Bush Administration in the 'war on terror' (presenting coercive interrogation, extraordinary rendition, surveillance and other 'exceptional measures' in a positive and necessary light). ${ }^{11}$ On this reading, The Dark Knight seemed to present one of

\footnotetext{
${ }^{8}$ Christiansen (2000), p 107; Shaun Trent noted in 2009 that since 2001 more comics-based superhero movies have been released than in all prior years combined: Trent (2009), p 105. The number and intensity of films released since then has, if anything, increased with the range of Marvel films in the Avengers Franchise (Iron Man 2 (2010), Thor (2011), Captain America (2011), Marvel's the Avengers (2012), Iron Man 3 (2013), Thor: The Dark World (2013), Guardians of the Galaxy (2014), Captain America: Winter Soldier (2014), Avengers: Age of Ultron (2015)) the Superman reboot with Man of Steel (2013) (and Batman v Superman: Dawn of Justice coming in 2016) and Spider-Man reboot with The Amazing Spider-Man (2012) and The Amazing Spider-Man 2 (2014) and not to mention the conclusion to Nolan's trilogy The Dark Knight Rises (2012). See also Gray and Kaklamanidou on the 'superhero decade': Gray and Kaklamanidou (2011), p 1.

${ }^{9}$ For a recent discussion of superheroes in wartime, see Bainbridge (2015).

${ }^{10}$ 'It is the first true, post $9 / 11$ superhero movie; one that looks at the use of chaos as a tool of terrorism while exploring the paper thin line between good and evil.' Crouse (2009).

${ }^{11}$ Ackerman (2008); Klavan (2008); Allen (2008); Bolt (2008); NY Times Editorial Board (2008). See the discussion of these claims by Ip (2011).
} 
the strongest endorsements of the need for exceptional measures in response to extraordinary circumstances. ${ }^{12}$ These reviews were met with a cacophony of critical responses, particularly in the blogosphere, that challenged the conservative reading of the film arguing that, instead, Nolan was presenting a critique rather than an endorsement of Bush politics and that Batman's considered recourse to exceptional measures was in contrast to those seen in reality. ${ }^{13}$

The scholarly response to The Dark Knight was also unprecedented with a range of rich and varied explorations of the film discussing the exceptional relation between the superhero, law and justice, the ambiguities of tactics for fighting terrorism, the nature of the presentation of evil, the theatricality of the superhero, the superhero as a figure of the threshold or boundary and filmic means for therapeutic-meaning-making in response to the $9 / 11$ attacks. ${ }^{14}$ As John Ip points out, features of the film such as its brooding and gritty presentation, 'the Joker's grainy homemade videos, cell phonedetonated human bombs, burnt-out remains of buildings swarming with rescue workers - give the film a distinctly post-9/11 aesthetic'. ${ }^{15}$ In this reading of the film the Joker (Heath Ledger) is a terrorist figure, threatening, intimidating and inflicting violence and mayhem and who, as Bruce Wayne's butler Alfred (Michael Caine) puts it, just wants to 'watch the world burn'. ${ }^{16}$ As such, Ip describes The Dark Knight as a parable about 'the dilemmas that face society when confronting terrorism and terrorists'. ${ }^{17}$ This notion of The Dark Knight as a parable is taken up by Michael Nichols who situates the film within the tradition of the 'combat myth' where a figure of order (the hero or god) defends the ordered world or city against the onslaught of chaos (the monster). ${ }^{18}$ This model of the combat myth recounts how the social order is continuously preserved from the onslaught of ever-recurring threats to peace and civility by the heroic actions of a particular individual. It thus provides a broad mythic framework in which the superhero genre can be analysed - whenever a monster or villain arises that cannot be dealt with by the normal mechanisms of law enforcement, a superhero arrives on the scene and, after a heroic effort, restores order (until the next monster arrives or the villain escapes). ${ }^{19}$

It is this aspect of the superhero genre in particular that highlights the exceptional relationship between the superhero and the law. For, whilst one of the drivers of the superhero franchises is the seemingly never-ending battle between the superhero and the supervillain - brought to life now in $3 \mathrm{D}$ and surround sound - the general role

\footnotetext{
${ }^{12}$ See in particular Klavan (2008), Ackerman (2008) and Bolt (2008).

${ }^{13}$ Cogitamus (2008); Orr (2008); Y Ylesias (2008). See also Ip (2011) who specifically analyses the post-9/11 context of The Dark Knight and proposes it as a critique of the Bush Administration's tactics.

${ }^{14}$ Trent (2009); Phillips (2010); Žižek (2010), pp 59-61; Schlegel and Habermann (2011); Muller (2011); Gaine (2011).

${ }^{15} \mathrm{Ip}$ (2011), p 213.

${ }^{16}$ As Ip notes, the Joker, however, is an imperfect fit for Osama Bin Laden (despite the claims of critics like Klavan) and instead Ra's Al Ghul, the villain from Batman Begins, is a better fit. See Ip (2011), p 213, note 20. See also Marano (2008) referred to by Ip.

${ }^{17}$ Ip (2011), p 213.

${ }^{18}$ Nichols (2011), p 236; Cohn (2001), p 42.

${ }^{19}$ Nichols sees Nolan's The Dark Knight in particular as an updated version of the combat myth with Batman representing democratic society and the Joker, chaos and terrorism: Nichols (2011), pp 236-237. See also Reynolds discussion of the 'extra effort' motif in the superhero genre: Reynolds (1992), pp 41, 65-66.
} 
of the superhero within society is a fight for justice alongside or as a supplement to the role of the law. ${ }^{20}$ Some superheroes, such as Superman, do this in an authorised form and are unwilling to break the law to achieve their ends. ${ }^{21}$ Others, such as Batman, see the law itself as fallible or broken and thus believe it necessary to go beyond the law to achieve justice. $^{22}$ These vigilante-superheroes are often antagonistic to the law and regularly break it in their quest for justice - even though they are operating for the laudable goal of justice, their actions themselves are criminal. ${ }^{23}$ However, another way to understand the relationship of the superhero to law is in terms of the concept of 'the exception' described by German jurist Carl Schmitt and his modern reader, Giorgio Agamben. ${ }^{24}$ From this perspective, the role of the superhero could be seen as responding to a 'state of exception' in which the ordinary operation of the law is suspended to deal with a crisis or emergency. This view would see the role of the superhero as not a permanent supplement to an ever-deficient legal system, but rather as a temporary measure to address a specific crisis.

Cultural legal scholar Jason Bainbridge posits that the 'superness' of superheroes means that they are automatically outside the law and thus attempts, drawing on Agamben, to think their status in terms of the notion of 'alegality'. ${ }^{25}$ However, to describe superheroes as simply exceptional beings (due to their superpowers) is really only to see them on a continuum with ordinary human beings. Whilst enforcing the law against someone as strong as Superman may be problematic, this by itself does not necessarily mean that Superman has an exceptional relation to the law. ${ }^{26}$ Figures like Batman, however - particularly in the 'realist' mode that Nolan adopts in his films - do not have this same innate 'superpower' and derive their status and ability from training, wealth and determination. At the same time, the concept of 'alegality' is important because it points to a different classification or understanding of the role of this type of superhero - not simply as a vigilante who is effectively a criminal, breaking the law in the desire to achieve justice, but as having a different relationship to the law.

For Schmitt, as Agamben points out, the exception is structurally connected to the figure of the sovereign - thus his oft-quoted phrase '[s]overeign is he who decides on

\footnotetext{
${ }^{20}$ For a discussion of the interdependence of the superhero and the supervillain in relation to law see Peters (2012).

${ }^{21}$ Vollum and Adkinson (2003), pp 100-101; Reyns and Henson (2010), p 51.

${ }^{22}$ Vollum and Adkinson (2003), pp 100-101; Reyns and Henson (2010), p 51.

${ }^{23}$ Bainbridge notes that Spider-Man in particular spends as much time trying to avoid the police as fighting the supervillains and Miettinen refers to Frank Miller's The Dark Knight Returns where Superman pontificates about Batman's acceptance of the superheroes as criminals. See Bainbridge (2012), pp 225-226; Miettinen (2011), p 135; Miller et al. (1986).

${ }^{24}$ Schmitt (2005); Agamben (1998); Agamben (2005). The use of Agamben's work on the 'state of exception' to analyse superheroes in general, and particularly based on the status of their super-powers, is taken up by Miettinin and Bainbridge: see Miettinin (2011); Bainbridge (2012); Bainbridge (2015). The connection of Agamben's broader work on the concept of homo sacer is also examined by Nayar (2006) (referred to by Bainbridge) and Spanakos (2011) (in relation to the Incredible Hulk). McGowan also draws on Schmitt and Agamben in his 'exceptional' (pun intended) analysis of The Dark Knight: McGowan (2009).

${ }^{25}$ Bainbridge (2012), pp 218-219, 226-227. McGowan also claims the non-conformity to the 'laws of nature' as a basis for the exceptionality of superheroes such as Superman: see McGowan (2009), paras 3-4.

${ }^{26}$ Though see McGowan's reference to Hegel who describes the hero (who is a law unto himself) as the antithesis to modern law: McGowan (2009), paras 4-5.
} 
the exception'. ${ }^{27}$ The Dark Knight specifically references this connection between the exception and sovereignty when, early in the film at a dinner with Harvey Dent, Rachel Dawes (Maggie Gyllenhaal) and the Russian ballet dancer Natascha, Bruce Wayne (playing devil's advocate) pitches the question 'Who appointed the Batman?' Harvey Dent, the District Attorney, then provides quite a specific justification for Batman:

We did. All of us who stood by and let scum take control of our city ... When their enemies were at the gates, the Romans would suspend democracy and appoint one man to protect the city. And it wasn't considered an honour it was considered a public service.

Instead of subscribing to the idea that Batman is a criminal vigilante on a personal vendetta for justice, Dent legitimises the role that Batman has taken. He argues that there is a need for Batman because the people of Gotham have allowed criminals to take over and control the city. Ip rightly identifies this reference to the Roman paradigm of the dictatorship ${ }^{28}-\mathrm{a}$ 'specific kind of magistrate whom the consuls had chosen and whose imperium, which was extremely broad, was conferred by a lex curiata that defined its aims'. ${ }^{29}$ In this sense, Dent is arguing that the people had appointed Batman as their protector to deal with the situation in Gotham, the basis for his position being appointment by popular sovereignty. ${ }^{30}$ Agamben, however, makes a distinction between the notion of dictatorship and the theory of the state of exception (despite Schmitt's first examination of the exception being in his work Dictatorship $^{31}$ ). Rather than embodying the role of dictatorship, Agamben situates the state of exception within the Roman concept of the iustitium (distinguished from the imperium provided to the dictator). Whereas the dictatorship involved the empowering of a particular magistrate with a specific mandate, such as waging war or quashing an uproar, the proclamation of the iustitium, a 'standstill' or 'suspension of the law', would follow a decree declaring a tumultus, 'an emergency situation in Rome resulting from a foreign war, insurrection, or civil war'. ${ }^{32}$ The tumultus was not so much the external threat to the state itself but the effect of that threat on the city in terms of the 'state of disorder or unrest' that the threat produced. ${ }^{33}$ Whilst Agamben acknowledges that it has been interpreted in relation to the concept of dictatorship, the result of the iustitium is quite distinct. The iustitium suspends the law and all legal prescriptions are put out of operation - at that point no Roman citizens, whether a magistrate or a private citizen, have any legal powers or duties. ${ }^{34}$ For

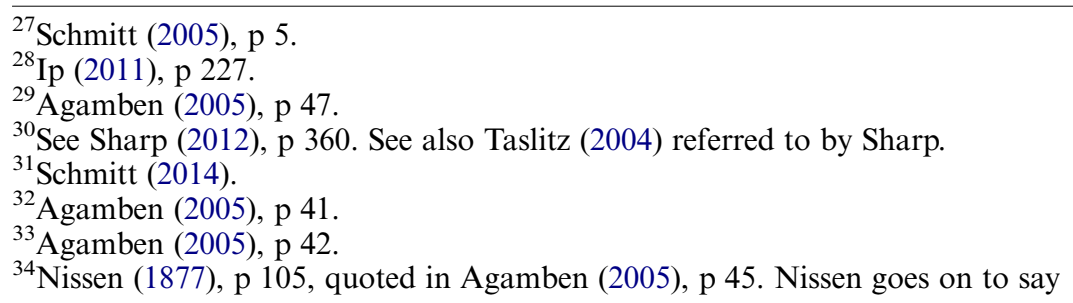

When the law was no longer able to perform its highest task - to guarantee the public welfare - the law was abandoned in favor of expediency, and just as in situations of necessity the magistrates were released from the restrictions of the law by a senatus consultum, 
Agamben, the connection of the iustitium and the tumultus to the state of necessity means that they 'are not categories of criminal law but of constitutional law, and they designate "the caesura by means of which, from the point of view of public law, exceptional measures may be taken". 35

This distinction between the concept of the state of exception and the dictatorship raises a different question about the role of the superhero and, more specifically, of Batman's role in Gotham City. Does Batman operate simply as a stop-gap dictator, who always has the potential of never giving up the power provided to him, ${ }^{36}$ or does he operate under a 'state of exception'? If the answer is the latter, to return to us to Schmitt's key point (the link between the exception and sovereignty), then the real question is not 'who appointed the Batman?' but 'who declared the state of exception?' The way Batman positions himself and his role in relation to the city is as an agent of change. As such, the state of exception or emergency in the city that he is responding to is not the rise of the terrorist activities of the Joker (though given the tumult that he causes, they would provide grounds for such a declaration) but rather the corruption and domination of the mob. All of which points to the fact that Nolan's presentation of Batman is not as a figure who restores the social order from the disruption by villains such as Ra's Al Ghul, the Joker or Bane, but rather to disrupt the exceptional basis of the situation itself - the corruption and crime-dominated experience of Gotham City. Reading Batman in this way sees him not as a vigilante criminal operating beyond the law, but rather as a figure of sovereignty operating in the space of the law suspended. Batman is neither executing the law (in terms of upholding it as authorised, covertly or overtly, by the police) nor transgressing it (in terms of being a criminal vigilante) but, to use Agamben's terminology, he inexecutes the law in the state of exception. ${ }^{37}$

so in the most extreme situations the law was set aside. Instead of transgressing it, when it became harmful it was cleared away; it was suspended through a iustitium. (Nissen 1877, p 98 quoted in Agamben 2005, p 45)

${ }^{35}$ Agamben (2005), p 46 quoting Nissen (1877), p 76.

${ }^{36}$ A point which Rachel Dawes makes, clarifying Harvey's reference to Rome by noting that 'the last man that they appointed to protect the republic was named Caesar and he never gave up his power'. See also Ip (2011), pp 227-228.

${ }^{37}$ Agamben (2005), p 50. See Peters (2014), p 122 and pp 117-125 where this analysis was initially developed. Jason Bainbridge has recently made a similar claim in relation to the role of a number of superheroes more generally such as Captain America (see Bainbridge (2015), pp 12-13) and, as noted above, has attempted to think the superhero in general through the concept of the state of exception (Bainbridge (2012) and Bainbridge (2015)). However, whilst superheroes, by their very nature, tend to respond to emergencies and extreme acts beyond the law, this does not mean that they are always (or even regularly) 'appropriating the sovereign decision' - rather, in many cases they are either part of the mechanisms of the state (even if only loosely tied) or engaging in criminal activity. In considering Batman's actions in relation to the roles of dictatorship and the doctrine of the state of exception the debate moves away from the 'criminality' of his actions (which, of course, is the initial response) because the issue of sovereignty is not about criminal law but constitutional law (though this emphasises the ambiguous and exceptional relation of the sovereign to the order of law itself). The question of the 'legitimacy' of Batman's actions, in the same sense, is founded not on an operation with the police or a popular proclamation of Roman dictator, but Batman's appropriation of the sovereign decision - his ability to stand in the place of the sovereign and declare the state of exception. This claim is problematised in the film where Harvey Dent at the press conference acknowledges that Batman is an outlaw who, one day, should answer for the crimes he has committed. What is interesting, 
This reading of Batman challenges the traditional mythic framework that Nichols proposes. It also emphasises the way in which Nolan transforms, inverts or otherwise 'makes strange' the superhero genre. ${ }^{38}$ For, rather than fighting for justice 'beyond the law', Batman consistently fights against particular visions of justice. This is most clearly seen in Batman Begins where the 'villains' (Ra's Al Ghul and the League of Shadows) want to wipe out Gotham City not for any personal gain but because of its corruption. They present a vision of 'justice as balance' which requires them to enact a 'return to harmony' by destroying Gotham City (just as Sodom was destroyed by the hand of God in the Old Testament). ${ }^{39}$ Bruce Wayne/Batman's response is similar to the figure of Abraham, arguing with Ra's Al Ghul that there are still 'good people' in Gotham and that Gotham is worth saving. ${ }^{40}$ In The Dark Knight Rises this thematic returns. Whilst muted under the visual depictions of class warfare and the revolutionary tone of Bane's semi-comprehensible speeches (referencing the storming of the Bastille in his call for the release of the criminals from Blackgate prison), the ultimate goal for Bane and Talia Al Ghul (Ra's Al Ghul's daughter) is to destroy Gotham in an attempt to restore harmony to the world. As such, it is the villains that embody a conservative 'tough on crime' approach to justice and who are wanting to enact that justice beyond the limits of the law. ${ }^{41}$ Whilst the League of Shadows presents this form of retributive 'Old Testament' justice, seeking to violently wipe out evil and corruption and restore balance to the world, the key villains of The Dark Knight (the Joker and Harvey 'Two-Face' Dent) also represent certain embodiments of justice, though more subtly defined. The next two sections of this article present particular readings of these characters, which challenges their traditional roles within the Batman mythos. In particular, we see that the role of Harvey Dent displaces the centrality of the Joker to The Dark Knight, and at the same time embodies the traditional mode of the vigilante-superhero. My argument is that this shifting of the traditional roles of the superhero mythos situates Batman differently (and opens up the possibility of the Christological reading of Batman that I wish to progress).

\section{3. 'When the chips are down, these "civilised people" will eat each other': the Joker, Hobbes and the state of nature}

In his Girardian reading of The Dark Knight, Bellinger argues that the Joker is a figurative version of Satan whose 'main purpose is to sow chaos, confusion and destruction among human beings'. ${ }^{42} \mathrm{He}$ argues that the Joker claims that it is the system of law and order, as much as the desire to punish criminals, which is immoral and

however, is the way Agamben ties the figure of the 'outlaw' to the 'sovereign' - see Agamben (1998), pp 104-115.

${ }^{38}$ For a consideration of the way Nolan's films transform or cross genre boundaries see McGowan (2012). See also Johnson (2014) who discusses a number of ways that Nolan's construction of Batman differs quite specifically from the superhero canon and mythos. On the concept of 'making strange' see Peters (2016).

${ }^{39}$ See Peters (2007).

${ }^{40}$ See Genesis 18: 16-33.

${ }^{41}$ In Batman Begins, Ra's Al Ghul (known at the time as Ducard) explains to Bruce Wayne that '[c]rime cannot be tolerated. Criminals thrive on the indulgence of society's "understanding".'

${ }^{42}$ Bellinger (2009), para 5. Cf. Nichols (2011), p 238. 
hypocritical. ${ }^{43}$ On this reading, the Joker reveals 'law abiding society' as a mystification, and his proclamation that the 'only sensible way to live in this world is without rules' is an accusation of the failure and hypocrisy of the laws and prohibitions that society invents to contain violence. ${ }^{44}$ Slavoj Žižek picks up on this type of critique by pointing out that, in a film that is all about the privileging of lying as a social principle, the Joker is a revolutionary figure of truth who desires to uncover the lies of society: 'the attacks will stop only when Batman takes off his mask and reveals his true identity'. ${ }^{45}$ In this way Žižek privileges the role of the villain. Todd McGowan's reading of The Dark Knight also privileges the role of the Joker as presenting a form of social critique and providing the possibility for the otherwise self-interested and self-serving citizens of Gotham City to engage in a truly ethical act. For McGowan, like Bellinger, the anarchic, critical perspective presented by the Joker is tied to a response to, or understanding of, the role of the law. Drawing on the moral philosophy of Immanuel Kant, McGowan argues that our commitment or devotion to the law is never 'for its own sake but for some attendant pathological motivation'. ${ }^{46}$ We are tainted by an originary 'radical evil that leads us to place our incentives of self-love above the law and that prevents us from adhering to the law for its own sake ${ }^{47}$ - we obey the law, not for the law itself, but because it is in our interests to do so. The result of this originary radical evil is a consequentialist ethics that seeks not the moral worth of the action itself (obedience to the moral law), but rather the ultimate benefit of the action to the individual. ${ }^{48}$ This is a morality of calculation or, as the Joker claims in relation to Gotham City, of 'plans' and 'scheming'.

McGowan argues that the Joker's critique of 'scheming' seeks to overcome this calculating thinking by allowing the space for a truly ethical act - one not caught within a consequentialist or utilitarian pathology. The basis for this reading is McGowan's analysis of the dialogue between Dent and the Joker after Dent's disfigurement. The Joker provokes Dent by arguing that the problem with society is that it is full of 'schemers trying to control their little worlds'. The Joker describes himself not as a schemer but as attempting to 'show the schemers how pathetic their attempts to control things really are'. Following this reasoning, McGowan argues that when the Joker sets up abhorrent ethical situations (threatening to blow-up a hospital unless someone kills the Wayne Enterprises lawyer who is about to disclose who Batman is; or giving a

\footnotetext{
${ }^{43}$ Bellinger (2009), paras 5-6, 9.

${ }^{44}$ Bellinger (2009), para 9.

${ }^{45}$ Žižek (2010), p 60.

${ }^{46}$ McGowan (2009), para 23.

${ }^{47}$ McGowan (2009), para 24; Kant (1998), p 59; Kant (1996).

${ }^{48}$ As McGowan notes, 'adherence to the law designed to procure some object or some ultimate good leaves one inevitably bereft of freedom'. (2009), para 30. Kant outlines this point in the Groundwork of the Metaphysics of Morals where he claims that
}

[i]f the will seeks the law that is to determine it anywhere else than in the fitness of its maxims for its own giving of universal law - consequently if, in going beyond itself, it seeks this law in a property of any of its objects - heteronomy always results. The will in that case does not give itself the law; instead the object, by means of its relation to the will, gives the law to it. (Kant 1996, p 89; quoted by McGowan) 
ferry full of criminals and a ferry full of 'innocent citizens' the detonator to blow each other up and threatening to do it himself if they do not decide in 15 minutes) he in fact provides a way for the people in those situations to break out of their self-interested calculating and scheming - giving them the opportunity to privilege the act itself rather than any benefit they may gain. ${ }^{49}$ These opportunities present a utilitarian calculation - justifying the death of one man to save all those in the hospital; or justifying the deaths of the criminals who have 'had their chance' in order to save the 'innocent civilians'. The result, in McGowan's view, is that

[t]he Joker's evil provides the basis for any ethical heroism because it highlights and strives to eliminate the evil of calculation that defines the subject's original relation to the law. $\mathrm{He}$ thereby constitutes the ground on which the ethical act can emerge. ${ }^{50}$

The problem with this reading of the Joker, however, is that it is based in substance upon the Joker's self-description. McGowan argues that when the Joker describes himself as 'a dog chasing cars' that 'wouldn't know what to do if [it] caught one', that he is presenting a priority of 'the act' over its consequences. That is, that the Joker does not have a plan and is focused on the ethical stance of 'the act' itself. As the Joker says to Harvey Dent, 'I just do things.' Yet, to take anything that the Joker says at face value is problematic. In line with his mythical figuring as a Satan or trickster figure, the Joker operates on the premise of deceptions, half-truths and bad jokes. For example, after having recovered the mob's pile of cash, the Joker emphasises that he is a 'man of his word'. The mobster finds this hard to believe when the Joker's men start to burn the cash. In response, the Joker claims that he is only burning his half. This is of course true, though it makes no guarantees as to

\footnotetext{
${ }^{49}$ In this sense, McGowan argues that the Joker encompasses a truly consistent ethical position. That is, following the Kantian position, the Joker encourages or provides the opportunity for individuals to make a decision that is not about their own self-interest but a following of the moral law for the sake of the moral law (that is, an adherence to the categorical imperative). McGowan acknowledges that the Joker himself would appear to hold a position that Kant believes cannot exist for humanity (that of the figure of diabolical evil who elevates evil to his good). However, he also points out (drawing on Alenka Zupančičs reading of Jacques Lacan's famous essay 'Kant avec Sade') the structural identity between the position of diabolic evil and the supreme good. That is, the person who follows the law for the sake of the law is structurally the same as the person who commits evil not for any gain but for the sake of evil itself: McGowan (2009), para 30; Zupančič (2000), p 92; Lacan (1989). Following McGowan, then, one way of reading the outcome of the 'prisoners' dilemma' on the ferries, where neither the ferry of criminals nor the ferry of citizens actually pulls the trigger, is to see this as a breaking out of the calculating mechanisms of a utilitarian pathology (though McGowan notes the way Nolan complexifies the naïve version of this reading in the film). As such, the decision not to blow each other up could be read as a following of the moral law for its own sake. The problem, again, with that reading is that if we turn to game theory (from which the prisoner's dilemma scenario itself arises), then it is directly because of one's self-interest that we should take the more noble action (in the prisoner's dilemma of not ratting out your partner in crime, in this circumstance of not blowing up the other boat). As such, despite the supposed potential for the Joker's actions providing a means to a deontological ethics, the scenarios themselves are still based on consequentialist actions - which indicates that the Joker (and this is hardly surprising) is not really encouraging or embodying a Kantian ethic at all.

${ }^{50}$ McGowan (2009), para 46.
} 
what will happen to the other half. ${ }^{51}$ If the Joker consistently operates through halftruths and deceptions, then can we believe his discussion with Harvey?

In response to Harvey's rage towards the Joker about the killing of Rachel, the Joker explains that he was 'sitting in Gordon's cage' when she was kidnapped. Dent's response is that it was the Joker's men and the Joker's plan. The Joker, dressed as a female nurse (complete with wig), turns and poses the question to him: 'Do I really look like a guy with a plan?' Throughout the rest of the dialogue, when the Joker accuses the mob, the cops, Gordon and even Dent of having plans which he takes pleasure in disrupting, he never actually says that he himself does not have a plan. ${ }^{52}$ The truth of the matter, as is unveiled throughout the film, is that the Joker does have a plan. ${ }^{53}$ The Joker meticulously plans his escapades, taking into account the expected responses to his actions and incorporating them into his plan. For example, the Joker allows himself to be caught by the police (after a spectaclefilled chase scene which included the vertical flipping of a semi-trailer) so that he can be put in the holding cell at the Major Crimes Unit, where Lau, the mob's accountant, is also being held. His subsequent escape is enabled by the use of a 'human bomb' in the holding cell, which the Joker triggers via a phone call after goading the supervising officer into attacking him. Thus, despite all the rhetoric presented by the Joker about being a disrupter of plans, he, in the end is the greatest planner and schemer of them all. The question, then, is: what is the Joker's plan? Is it simply that, as is so often quoted, he just wants to 'watch the world burn'? ${ }^{54}$

Rather than seeing the Joker with all his chaos-inducing activity as a figure of diabolical evil set to disrupt and destroy all society's institutions, my argument is that the Joker in effect simply demonstrates quite a conservative position in relation to law and justice: that the law is the means of repressing a fundamental violence underlying socalled civil society. In the most detailed face-to-face interaction between the Joker and Batman (in the 'interrogation' scene at the Gotham Police Station), the Joker derides the morals and code of society as just a bad joke 'dropped at the first sign of trouble'. His critique is that people are 'only as good as the world allows them to be ... when the

\footnotetext{
${ }^{51}$ Later in the film, when the Joker eventually provides the addresses where Harvey Dent and Rachel Dawes are being held, he provides the correct addresses but inverts them. The result is that Batman's decision to save Rachel results in him saving Harvey. Finally, in Batman's concluding showdown with the Joker, there are a number of hostages trapped in a high-rise building. The police are about to enter the building as they can see who they believe to be the hostages being held captive by men with clown masks (as were used by the Joker's men in the bank heist at the beginning of the film). However, it is the hostages that are wearing the clown masks with guns taped to their hands. This would have resulted, without the intervention of Batman, in the police killing the hostages when they failed to down 'their' weapons.

${ }^{52}$ It is important to note that McGowan's analysis of this scene is based on a print version of the script of the film and not the film itself. In the script, the Joker opens this dialogue with 'I don't have a plan.' In the film itself, this is transfigured into the question posed to Harvey 'Do I really look like a guy with a plan?' The change is important (and goes to Ledger's brilliant interpretation of the character) because it fits with the Joker's play on the truth. See McGowan (2009), para 29.

${ }^{53}$ The question raised by Dent is accusatory, indicating that it was the Joker's plan that resulted in the death of Rachel (which of course is true). The Joker magnificently deflects this accusation by posing the question above and asking Dent to make a judgment about whether the accusation makes sense. He never answers the question himself.

${ }^{54}$ See, for example, Phillips (2010), pp 33-35, McGowan (2009) note 15 and Nichols (2011), p 241 who describes this as a neat summary of 'the Joker's sole motive'.
} 
chips are down, these ... these "civilised people", they'll eat each other'. The core of the Joker's program, the underlying reason for the chaos and madness he unleashes on the city, is that under pressure everyone will revert to a self-interested state of nature, a Hobbesian war of all against all. ${ }^{55}$ As such, the Joker critiques the laws and rules of society: 'you have all these rules and you think they'll save you'. For the Joker, the truth appears to be that 'the only sensible way to live in this world is without rules'. It is in this sense that the Joker identifies himself as an agent of chaos - in terms of a particular critique of the violence of the existing order of Gotham itself. Returning to the extended scene with Harvey Dent, the Joker outlines his understanding of plans as follows:

\begin{abstract}
You know what I've noticed? Nobody panics when things go 'according to plan'. Even if the plan is horrifying! If, tomorrow, I tell the press that, like, a gang banger will get shot, or a truckload of soldiers will be blown up, nobody panics, because it's all 'part of the plan'. But when I say that one little old mayor will die, then everyone loses their minds!... [Handing Harvey a gun and pointing it at himself]... Introduce a little anarchy. Upset the established order, and everything becomes chaos. I'm an agent of chaos. Oh, and you know the thing about chaos? It's fair!
\end{abstract}

What the Joker's diatribe suggests is not so much that he is presenting a chaos that will challenge the law as much as the fact that chaos and violence are already implicated and presupposed by the law. The Joker does not reveal a 'state of nature' before or beyond the law but rather demonstrates the nature of the law itself - that the law is premised on a state of war of all against all. ${ }^{56}$ In doing so, he proposes that the terrorising element of law is that it determines legitimate violence - it designates who may be killed according to the plan with impunity (soldiers who are designated as military deaths, criminals who, if not killed on the streets or by the police, will be subjected to the violence of the law's punishment) and who may not. This points to the violent nature of the law itself because it is responding to violence - yet, this response to violence is by necessity another form of violence. ${ }^{57}$ All of the Joker's escapades draw out not only the presumed violence of a state of nature, but the violence of the law itself. Rather than being a radical figure of evil, or a revolutionary figure of the truth, the Joker ends up embodying a much more conservative position, because all of the Joker's activities are premised on the law.

For Hobbes, the 'state of nature' is the necessary foundation of the State and law itself. It is in response to the 'state of nature' that the all-powerful sovereign is needed and individuals give up their rights to violence to the State in return for the State's protection. ${ }^{58}$ Following Agamben's analysis, in return for protection from each other, individuals agree to become homo sacer - he who may be killed with impunity but not sacrificed - in relation to the State ${ }^{59}$ The state of nature, from which individuals have exited, is then incorporated into the city via the violence inherent in the sovereign exception:

\footnotetext{
${ }^{55}$ See Hobbes (1952) chapter XIII, pp 84-86.

${ }^{56}$ Hobbes (1952) chapters XIII and XVII, pp 84-86, 99-101 (in particular pp 100-101).

${ }^{57}$ Milbank (2003), pp 36-38 and chapter 2 in general. For the two classic analyses of the relation between violence and the law see Benjamin (1986) and Cover (1986).

${ }^{58}$ Hobbes (1952) Introduction and Chapter XVII, pp 47, 99-101.

${ }^{59}$ Agamben (1998), p 106; Hobbes (1952), chapter 21, pp 112-117 (in particular pp 113-114).
} 
[t]he state of nature is ... a state of exception, in which the city appears for an instant ... tanquam dissoluta. The foundation is thus not an event achieved once and for all but is continually operative in the civil state in the form of the sovereign decision. ${ }^{60}$

The law thus presupposes itself as instituted against a state of nature, a chaos or anarchy that would rule without it. The assumption of anarchy and chaos, however, is an assumption internal to the law. As such, the Joker's activities themselves are premised on the operation of the law. His provocative disruption of the law's operations does not challenge it but rather strengthens its force - the disruption of order privileges rather than undermines that order.

The battle between Batman and the Joker which dominates so much of the screen time and appears to be the central premise of the film, would therefore supposedly encompass two sides of the violence of the law: the anarchy of the 'state of nature' and the violence of the sovereign exception. However, as just noted, these two aspects of violence are structurally identical - Batman and the Joker appearing as two sides of the same coin. This would reflect the general reading of the film in relation to the comic-book tradition and Nichol's mythical references. ${ }^{61}$ The problem with this reading is that in the end Batman refuses to embody the violent operation of the state of exception/state of nature. Whilst in the earlier interrogation scene he attempts to use violence against the Joker, what he discovers is that the violence itself promulgates more violence (which the Joker is expert at manipulating). In the final showdown, Batman's response to the Joker changes. He refrains from enacting physical violence on his body aimed at retribution or penance, or exercising the sovereign right of life and death, but returns to a use of violence purely as a preventative action. ${ }^{62}$ The Joker, revelling in the fight, exclaims that he and Batman are destined to do this forever. Batman disputes the claim, saying that the Joker will be in a padded cell. Despite having the opportunity to let the Joker fall to his death, Batman saves him. For, in the end, killing the Joker would simply prove his point, conflate violence with the law and conclude that the only solution to the problem of violence is death - at the hands of the sovereign. ${ }^{63}$ What thus occurs in this final showdown is a de-centring of the Joker from the narrative focus of the film. Instead of agreeing with the Joker's self-description as a diabolical figure of evil (which would encompass the never-ending battle between Good and Evil often depicted in the superhero genre, and, in particular, the Batman mythos with the ongoing clashes between the Caped Crusader and the Clown Prince of Gotham), Batman's rejecting of the Joker's games reduces him to the conservative figure of the criminal that needs to be

\footnotetext{
${ }^{60}$ Agamben (1998), p 109. Note also that in his qualification of Hobbes, Agamben claims that the political realm is not constituted in relation to citizens' rights, free will and social contracts, but that 'from the point of view of sovereignty only bare life is authentically political'. That is, 'Sovereign violence is in truth founded not on a pact but on the exclusive inclusion of bare life in the state.' Agamben (1998), pp 106-107.

${ }^{61}$ See, for example, Alan Moore's Batman: The Killing Joke, which works through the structural similarities of The Joker and Batman: Moore et al. (1988).

${ }^{62}$ For discussion of the connections between justice and penance in Western law see Sharp (2011).

${ }^{63}$ As such, Batman's ethical stance in refusing to kill the Joker itself shows the radicality of the position of the Batman. This is in contrast to the supposed ethical nature of the Joker. It is also in contrast to the previous filmic rendition of the showdown between Batman and the Joker in Tim Burton's Batman (1989) where the Joker, in the end, does fall to his death.
} 
restrained. Rather than an anarchical figure who is challenging the law itself, the Joker wants to show things 'as they really are'. He thus is not interested in changing the situation in Gotham City, either for good or bad. But the possibility of changing the situation in Gotham is the premise of the first part of the film, which is that the legitimate, public figure of the law could be the basis for change in Gotham City. It is for this reason that the conclusion of the film becomes not about the Joker who merely demonstrates the violent foundation of the law, but the figure of the lawyer who was supposed to change the city through the law itself: Harvey Dent. As such, it is to Harvey Dent that we must now turn.

\section{4. 'The only morality in a cruel world is chance': law, procedural justice and the toss of the coin}

Harvey Dent, in the early parts of the film, is presented as the figure of the 'heroic lawyer' who could achieve justice through the legal system, when Batman could only achieve it beyond or outside it. When Harvey claimed that Batman was operating in the role of the dictator or the figure of the exception who protects the city and the law in a time of crisis, he saw this as a legitimate position in relation to the law. At the same time it is Harvey who could implement justice through the law via his skills as an advocate (as seen in the trial scenes), his knowledge of nuances of legal cases and legislation (invoking 'RICO laws' as the basis for prosecuting the mob as a whole) and his use of both legal and political strategy (his justification to the mayor for the prosecution of the mob). ${ }^{64}$ It is his ability to bring justice through the law and his elevation as Gotham's 'white knight' that is the reason that Batman sees him as his replacement the legitimate role of the 'heroic lawyer' to replace the illegitimate role of the superhero ${ }^{65}$ - as well as the reason that the Joker decides to try and 'bring him down to our level' after the death of Rachel. As we saw above, the Joker does this via a critique of 'the plans' of Gotham City, its rules and laws, as well as his invocation to 'introduce a little anarchy', identifying himself as the agent of a chaos that is 'fair'.

For Harvey, who has suffered both physical deformity and the loss of his fiancé, the Joker plays upon the desire for meaning in the face of suffering. He claims that the meaning imposed upon life and upon tragic events is limited, arbitrary and faulty because it is caught up in the plans aimed at controlling the world. The meaningmaking power of law for which Harvey as a lawyer and Gotham's 'white knight'

\footnotetext{
${ }^{64}$ RICO refers to the US Racketeer Influenced and Criminal Organizations (RICO) Act 18 United States Code chapter 96. Whilst this is a federal Act (and thus Harvey Dent, as a District Attorney, would not be able to bring proceedings under it) most US States have enacted similar legislation. See, for example, the New York Penal Code Article 460.

${ }^{65}$ In this sense, we see a reference to another pop culture icon, ranging from Atticus Finch to Perry Mason. It is interesting to note this connection, which becomes quite specific in The Dark Knight, of the role of the superhero and the role of the heroic lawyer. Whilst in the Batman franchise these characters are divided between Batman and Harvey Dent, comic books have demonstrated more explicitly this connection in the roles of lawyer-superheroes such as Daredevil and She-hulk. For discussion of the 'heroic lawyer' in popular culture see, for example: Asimow (1996); Bainbridge (2006); Kamir (2005); Kamir (2009). Kamir notes the connection between the 'heroic lawyer' in popular culture and the genre of 'the western', a connection which Manderson pushes forward to the superhero genre. See Kamir (2005) and Manderson (2011). For a discussion of Daredevil as lawyer and superhero see Bainbridge (2007) and Sharp (2012). For an analysis of She-Hulk, see Mitchell (2015).
} 
stood - its ability to determine justice and punishment of the criminal - has failed. ${ }^{66}$ In contrast to Harvey's immediate attempt to blame the Joker for Rachel's death, the Joker points the blame at chaos - chaos, in its lack of determinate meaning is fair because it applies to everyone equally. It is this understanding of chaos that provides a means for Harvey to deal with the loss of Rachel as if it was an aspect of chance (later representing Rachel's death as a 50-50 chance). What is important here, however, is not that Harvey takes on the Joker's invocation of chaos directly but the way he interprets it through the act of tossing a coin. ${ }^{67}$

Instead of reproducing the Joker's picture of law as determined by a presupposed fundamental chaos, Harvey's role as a lawyer - enmeshed in the procedural aspects of the legal system, its notion of the rule of law, due process and procedural fairness - is heightened, rather than laid aside in his vengeful desire to kill all those involved in Rachel's death. His proclamation that 'chance is fair', then, is a reflection of the fairness supposedly embodied in the elements of procedural justice before the law. The point for Harvey, is not about substantive justice in terms of whether the accused is guilty or innocent, but rather about whether or not they receive a 'fair trial'. ${ }^{68}$ Even though Harvey goes beyond the law in terms of dealing a retributive justice, instead of taking up an exceptional status in relation to the law (like that of the superhero) he works to fulfil the very role of the law itself: to provide meaning to suffering in the sense of punishing the criminal. ${ }^{69}$ In taking up the goal of the law he also takes up its structural operations that are aimed not at substantive but procedural justice, compressing all the elements of legal procedural justice into a single toss of the coin. Harvey is thus distanced from making the determinant decision of justice the decision of life and death, of guilt or innocence, of the person accused - and rather focuses on ensuring an absolutely fair and equal access to such a decision of judgment determined by an arbitrary action. As Harvey shouts at Batman in the final scenes of the film: 'it's not about what I want, it's about what's fair!' Harvey's commitment to the process of justice implemented through the legal system is retained and incorporated into an objective system that embodies the conception of justice as

\footnotetext{
${ }^{66}$ See, for example, Berger's discussion of the precariousness of the criminal law's ability to determine justice itself: Berger (2008), pp 107-112.

${ }^{67}$ In a number of early scenes in the film, we find Harvey leaving what would be important decisions up to a toss of his father's lucky coin. After he confesses to being Batman and is being taken into custody he gives the coin to Rachel and the audience learns that it is a twoheaded coin. Instead of leaving things to chance Harvey 'made his own luck' (via the process of appearing to leave things to chance). After Rachel's death, one side of the coin is disfigured leaving a clear head on one side and a scarred/blackened image on the other - as such, the odds have changed.

${ }^{68}$ In one sense, Dent's invocation of the justice of chaos is a hearkening back to the medieval 'trial by ordeal' where the judgment occurs as a result of a particular process without decision-making occurring by a (human) judge. Rather, the outcome of the trial is supposedly determined by God in heaven. On earth, all we receive is the evidence of the decision one way or another (if someone thrown into the lake sinks and drowns then they were not a witch and will enter into heaven; if they float then they are witch and should be burnt at the stake and thus sent to hell).

${ }^{69}$ The challenge of this is the inability of law to provide meaning to the suffering of the victim. See Berger (2008), pp 107-112. On the question of evil as meaningless suffering, see Jefferey (2008), pp 13-32.
} 
chance. ${ }^{70}$ As he proclaims, "the world is cruel and the only morality in a cruel world is chance: unbiased, unprejudiced, fair'.

Batman's desire to return the mantle for protecting the city to the 'legitimate' figure of Harvey Dent is based on the idea that in the normal course justice can be achieved through the law. However, the focus on Harvey as Gotham's 'white knight' still encapsulates a sense of the heroic. It flags that the 'impartial' system of law is still determined by the fallible hands of corrupt police, lawyers and judges, and is thus reliant on the 'heroic lawyer' to manipulate the system to get a just outcome. ${ }^{71}$ Whilst after Rachel's death Harvey's belief in the legal system came crashing down, his commitment to a system that can produce justice does not. When Harvey goes out killing those that were involved in Rachel's kidnapping, he is not simply out seeking vengeance. Rather, his commitment to justice and legality takes over. Instead of looking to the fallible justice of a legal system reliant on multiple individuals who are all possibly corrupt, justice becomes a toss of the coin, based purely on chance and under which everyone's chance - everyone's access to justice - is the same. In this sense, Harvey's rendering of legality encompasses a critique of legal justice in terms of its formality - its focus on due process and fairness before the law, which is a systematic reliance on particular individuals to fulfil the rule of law itself. ${ }^{72}$ Harvey thus embodies the traditional critique of the law found in the superhero genre - that the law is fallible, inadequate and consistently fails to achieve justice. Instead of attempting to achieve justice in the role of the superhero Harvey attempts to perfect the system of law through a single action, which is not determined by the quality of the lawyer, the impartiality of the judge or the reliability of witness testimony. Access to justice becomes equal for all and all content is removed from the decision - all that is left is a simple, fair act: the toss of the coin.

This emptying of all content from the decision and displacing it into an objective act, highlights the structural role that the decision plays in law. Law, despite its claim to determinativeness, generality and applicability, is only brought into actuality through the legal decision. ${ }^{73}$ The application of the law is always reliant on a decision, whether by the judge in the ordinary course or the sovereign in the exceptional case. The decision, however, can only be implemented through the law's suspension in the very act of application. ${ }^{74}$ If a particular case were to be decided exactly in accordance

\footnotetext{
${ }^{70}$ On the consideration of the toss of the coin as an objective system comparative to the law, see Giddens (2015). On a reading of Harvey Dent as an archetype of the criminal prosecutor, see Rendleman (2009).

${ }^{71}$ Harvey's criticism of Commissioner Gordon is of Gordon's pragmatism by working with cops that had been investigated for corruption by Harvey when he was in Internal Affairs. In the end, it was the corruption of the police force that enabled the Joker and the mob to infiltrate and kidnap both Rachel and Harvey. John Milbank, in his analysis of the writing of Saint Paul outlines the contrast between trusting others and the supposed guarantees provided by law, courts and political constitutions. He notes that while trust may appear as a weak recourse in comparison to these guarantees, 'since all these processes are administered by human beings capable of treachery, a suspension of distrust, along with the positive working of tacit bonds of association, is the only real source of reliable solidarity for a community'. Milbank (2010), p 53.

${ }^{72}$ As Fitzpatrick notes, the law's determinateness always requires 'something other' in order to carry it out. The Law 'becomes the combination of determination with what is beyond determination'. Fitzpatrick (2001), p 76.

${ }^{73}$ Agamben (2005), pp 36-37; cf. Fitzpatrick (2001), pp 73-75.

${ }^{74}$ Agamben (2005), pp 39-40. See also Agamben (1998), p 20 where he notes
} 
with the law, then the judge is not actually deciding anything for the law already determines the outcome. Yet, in order to get from the generality of the law to the specificity of the case being considered, a decision has to bridge the gap between the general and the specific. As such, the decision fulfils a structural position within the law and cannot be predetermined (or else it would not be a decision). The judge needs to decide to make the law apply or not apply in the particular circumstance. ${ }^{75}$ This structural requirement within the law for a decision, however, risks the possibility of the decision being arbitrarily determined. This cannot be simply justified by recourse to 'applying the law' for applying the law to the particular circumstance already demonstrates that the application is something separate to and not captured within the generality of the law itself. In this sense, the legal decision becomes structurally indeterminate and devoid of predetermined content.

When Harvey elevates the legal system into the toss of the coin, he simply removes the fallibility of the individual deciding and leaves the decision to the toss of the coin. ${ }^{76}$ The potential for arbitrariness is dealt with by the law in terms of its focus on due process at one level and on the ability for appeal at another. Yet, the system of law itself in its implementation is concerned not so much with whether substantive justice is determined because, as Derrida is oft-quoted, justice is aporetic and can never be fully determined. ${ }^{77}$ The 'humanness' of law in its potential fallibility focuses on procedural justice, due process, fair hearings and proper recourse to appeal. This focus on form over substance is exactly what the superhero genre is seen as critiquing. ${ }^{78}$ Harvey's shift from enacting justice through the law to a fulfilling of justice beyond the law captures that element of vigilante justice traditionally seen in

[t]he validity of a juridical rule does not coincide with its application to the individual case in, for example, a trial or an executive act. On the contrary, the rule must, precisely insofar as it is general, be valid independent of the individual case.

See also Fitzpatrick (2001), pp 73-78 discussing Derrida (1992) in relation to the determinateness of the law with its responsiveness in relation to the decision of the judge.

${ }^{75}$ That is the law has to 'originate in each act of legal decision'. Fitzpatrick (2001), p 81. See also pp 74-75 where he quotes Derrida: 'each case is other, each decision is different and requires an absolutely unique interpretation, which no existing coded rule can or ought to guarantee absolutely' Derrida (1992), pp 23-24.

${ }^{76}$ It is worth noting here that this process of leaving decisions to the toss of a coin shifts in the film. Prior to his disfigurement, Dent would appear to leave certain decisions - whether he or Rachel would cross-examine a witness, or whether he would go through with the decision to turn himself in as Batman - up to the toss of the coin. However, whist these decisions had the appearance of chance (for which Rachel rebukes him), because the 'lucky coin' was twoheaded, Harvey was in fact manipulating appearances to present an otherwise pre-determined decision as undetermined. When the coin is disfigured, the odds change and the tossing of the coin does become left to chance. This shift symbolises Harvey's critique of the legal system - the supposed 'fairness' of trials provided by the courts in Gotham City too-often being corrupt and thus decisions being predetermined and subject to the manipulation of appearances. The transformation of the 'loaded' coin into a two-sided coin represents Harvey's shift from working within a system that manipulates appearances to one where justice can be delivered via the objective mechanism of a 'fair' toss of the coin. Thanks to one of the anonymous reviewers for emphasising this point.

${ }^{77}$ Derrida (1992).

${ }^{78}$ Which, as Sharp has demonstrated, follows certain general public perceptions and attitudes about law and justice. See Sharp (2012). 
the likes of Batman (and more fully in the character of Daredevil). ${ }^{79}$ At the same time, the structure of Harvey's actions conforms to the legal system and a legal decision compressed into a process that attempts to remove the potential for corruption (as he experienced in terms of the police) as well as arbitrary or influenced decisions (by judges or juries). The challenge of the law to deal substantive over procedural justice is compressed into a $50-50$ chance, which is always the same: the single toss of the coin.

Despite all of its procedural requirements, the law is reliant on the actions of individuals that can be corrupted and the decisions of individuals that could be arbitrary. The premise of the law, at one level, is a divine justice, and yet the human implementation of the law can never be measured against this justice. As such, the law is measured against procedural aspects - has due process been followed - rather than substantive ones which are always left to the indeterminacy of the legal decision. It is this potential for arbitrariness and corruption - the law's fallibility itself - that Harvey reveals in The Dark Knight. Yet, Batman's actions at the end of the film, instead of reaffirming the vigilante role of the superhero as the supplement of the law, open up the possibility for a different foundation for the community of the city and a different vision of legality - one based upon trust rather than a recourse to law. It is to this possibility that I now turn.

\section{Law, compassion and the non-hero: Batman as a typology of Christ}

The claim that I made at the beginning of this article, that Batman is a typology of Christ, relates not to any great sacrifice in The Dark Knight Rises nor to a sense that Batman is a divine figure in human form, ${ }^{80}$ but focuses quite specifically on the conclusion of The Dark Knight. After Batman's showdown with the Joker discussed above, the concluding sequence of the film follows Dent's kidnapping of Commissioner Gordon's family and his attempt to 'punish' Gordon for pragmatically working with crooked cops (which created the opportunity for Rachel's kidnapping and death) despite Dent's warnings. Dent takes Gordon's son and threatens to subject him to the toss of the coin - the same 50-50 chance that everyone else gets and that Rachel received. When Harvey flips the coin Batman tackles him, saving Gordon's son. Harvey, however, falls to his death (followed by Batman who is injured). In order to protect the good image of Harvey Dent and his prosecution of the mob, Batman takes the blame for Dent's killings. The film then concludes with Gordon and the police beginning the hunt for Batman. The framework of this conclusion is thus built around a particular form of deception. As Žižek points out, referencing a number of the old westerns such as those by John Ford, ${ }^{81}$ the message of the film appears to be that 'only a lie can save us' ${ }^{82}$ In the westerns, in order to civilise the Wild West, there is a need to 'print the legend' rather than the truth. Yet, whilst The

\footnotetext{
${ }^{79}$ See Bainbridge (2007) and Sharp (2012).

${ }^{80}$ Which is often embodied in the messianic presentation of Superman, particularly on film. See Schenck (2005) and Barkman (2013). For a Nietzschean reading of Batman, which compares him to the 'messianic' presentation of Superman see Robertson (2005).

${ }^{81}$ For example, Fort Apache (1948) and The Man Who Shot Liberty Valance (1962).

${ }^{82}$ See Žižek (2010), p 61. For a discussion of the connections between the superhero genre and the Western in relation to law, see Manderson (2011).
} 
Dark Knight presents a similar trope, it is inverted. In the John Ford films, the lie is in the form of giving someone credit for a heroic act they did not commit - glorifying the actions of those involved in founding events of the community. ${ }^{83}$ In The Dark Knight, however, it is not so much about giving credit for noble acts as it is about attributing blame to Batman for criminal acts he did not commit (the murders committed by Harvey Dent).

Nolan's conclusion to the trilogy, The Dark Knight Rises, presents a particular reading of these events seeing the lie promulgated by Gordon as inherently problematic. Eight years later he is wracked with guilt over the burden of this lie - which also includes accusing Batman of Dent's murder - and the deception of the people of Gotham City. Dent is remembered as a hero, a memory Gordon has fostered despite the fact that Harvey attempted to murder his son. Batman, in contrast, is remembered merely as a 'thug and a murderer' who killed the heroic Dent. This lie is presented as the political foundation for the Dent Act, which gives the police greater powers to tackle crime and lock-up criminals (mandatory sentencing, no parole). The deception also paves the way for Bane to masquerade as the great liberator of society from the oppressive lies of its rulers and present himself as the revolutionary revealer of the truth. He demands the release of the prisoners in Blackgate prison on the basis that they have been unfairly convicted and held under the Dent Act. This call for 'liberation' is followed by a process of 'bringing justice' to the police and powerful in Gotham City, effected via a pre-determined guilt with the mad-man Crane (the Scarecrow) overseeing 'sentencing hearings' which determine the fate of each individual: 'exile or death ... by exile'. All the while, of course, Bane harbours his own lie: that the nuclear bomb they are threatening Gotham City with will blow-up anyway, destroying the city, which requires Batman to return and supposedly die a heroic death in saving the city (though, as we noted in the introduction, Bruce Wayne does not actually die).

While this is how Nolan reinterprets his own films and the events of The Dark Knight, there is quite a different reading of the film that is possible. This reading is also prompted by the moral ambiguity and discomfort of the final scenes of The Dark Knight, but rather than seeing 'the lie' as a bad thing that will, in the end, result in more (not less) terror being brought down on Gotham City, it outlines a more serious structural challenge than simply the 'badness' of this deception. Earlier in the film, Batman's concluding actions are foreshadowed in a discussion between Bruce Wayne and his butler Alfred. Alfred argued that, despite the killings of the Joker, Batman should not give in to his demands. Rather, the whole purpose of Batman is that (despite being hated for such actions) he can endure the unendurable. So, when it comes to the final scene, Batman willingly takes the blame for Dent's murders and commits himself to being hunted and condemned as an outlaw so that the people will not lose hope in their 'white knight', the 'legitimate' hero of Gotham City. It is this presentation of a willing and necessary wrongful conviction, both in structure and motivation, that is the basis for a comparison between

\footnotetext{
${ }^{83}$ That is, in Who Shot Liberty Valence that Ransom Stoddard (James Stewart) shot Liberty Valence when it was in fact Tom Doniphon (John Wayne). In Fort Apache, that Captain York's (John Wayne) acknowledgement that Colonel Thursday (Henry Fonda) fought a glorious battle against the Apaches when in fact his arrogant tactics stupidly resulted in the death of most of his men.
} 
Batman and Christ and which goes to the possibility of a different founding of legality in the community. For from a legal perspective, the Christian Passion story in the gospel narratives is a story of a wrongful conviction: a man sentenced to death for crimes that could either not be identified or, where they are pointed to, were not committed. ${ }^{84}$ Yet, in the Christian tradition, it is this wrongful conviction and execution that founds a new community and a different relation to law. It is this structural similarity between Christ and Batman that I now wish to explore.

Theologian John Milbank notes that in the Christian tradition, Christ, the GodMan, 'died precisely a purely divine and a purely human, or even sub-human, death' ${ }^{85}$ The divine death was a result of resentment or envy at his elevated position - his claim to be divine. The human death, however, was at the hands of the arbitrary sovereign authority - via exclusion, as bare life. ${ }^{86}$ Drawing on Agamben, Milbank classifies Christ as homo sacer, abandoned, cast out and excluded from political life by the Jewish authorities, the Roman authorities and then by the mob. ${ }^{87}$ In this sense, Christ's death was not noble, heroic or with dignity but rather a death of 'utterly emptied-out humanity': 'he died the death that proves and exemplified sovereignty in its arbitrariness'. ${ }^{88}$ The scandal of the cross is that Christ was executed as a criminal and an outlaw: 'Jesus imbued with his divine height died precisely the death of absolute innocence. ${ }^{89}$ Yet, Christ's abandonment and execution is not the endpoint. For, as Milbank emphasises, it is not simply that we should identify with Christ as a victim. Rather, Christ's death on the cross and his exclusion from the law at each

\footnotetext{
${ }^{84}$ From the perspective of Christian orthodoxy, the accusations against Jesus were for blasphemy where he claimed equality with God. However, if one takes the Christian belief that Jesus was the Son of God (which is the perspective presented in the Gospels themselves), then the accusations of blasphemy are false. At the same time, the Gospel Narratives show the challenge of finding any crime to convict Jesus of and that the law of blasphemy was not punishable by death (at least whilst under Roman rule). See Milbank (2003), pp 95-96.

${ }^{85}$ Milbank (2003), p 95.

${ }^{86}$ Milbank (2003), pp 92-93, 97; Agamben (1998).

${ }^{87}$ See Matthew 26:57-27:26; Mark 14:53-15:15; Luke 22:66-23:25; John 18:12-19:16, ESV. Matthew, Mark and John's Gospels depict Christ as being questioned by the Jewish authorities (the Sanhedrin and the High Priest) and then being sent to Pilate. Luke also includes an account of Pilate sending Christ to Herod and then being sent back to Pilate again. Milbank notes that

[t]he only consistent thread in these narratives is that Christ was constantly handed over, or abandoned to another party. Judas betrayed his presence; the disciples deserted him; the Sanhedrin gave him up to Pilate; Pilate in turn to Herod; Herod back to Pilate; Pilate again to the mob who finally gave him over to a Roman execution, which somehow, improperly, they co-opted. Even in his death, Jesus was still being handed back and forth, as if no one actually killed him, but he died from neglect and lack of his own living space.
}

Later he notes that ' $\mathrm{h}] \mathrm{e}$ was shuttled back and forwards, with an undercurrent of indifference, as though not really dangerous ...' Milbank (2003), pp 82, 96. In addition, Milbank critiques the anti-Semitic readings of 'the mob' and the Passion narratives: Milbank (2003), pp 83-84, 87-89.

${ }^{88}$ That is, he died 'the death which any of us, under sovereign authority, in exceptional circumstances which always prove the rule, may possibly die'. Milbank (2003), p 96.

${ }^{89}$ Milbank (2003), p 97. At the same time, Milbank questions Agamben's analysis of homo sacer as not being offered as sacrifice rather noting that '[a]ll that is certain is that he was to be killed without ritual purification - but this is still consistent with a total offering, as indeed the Israelite examples attest: totally unclean towns were to be offered to Yahweh'. See Milbank (2003), p 92. 
level ('by the Jewish law of its tribal nation; by the Roman universal law of empire; by the democratic will of the mob'90) was a direct result of Christ's intentional failure to resist human power. Christ 'went freely to his death because he knew that a merely human counter-power is always futile and temporary'. ${ }^{91}$ Christ knew that the only true challenge to the violence of the law, the state and the people was a non-violent self-giving, ${ }^{92}$ and it is this non-violent act that forms the foundation of a new type of community based on the rejected and excluded one as the most envied and unrepeatable one. ${ }^{93}$

To return to The Dark Knight, my argument here is that Batman embodies a typology of Christ in this form of exclusion. In the final scenes of the film Batman takes up a position of exclusion that is structurally different to the superhero embodying of the sovereign exception. This is not to argue that Batman is Christ or even a stand-in for Christ, for, as Milbank has argued, the actions of Christ himself are utterly unrepeatable. Rather, it is that the actions of Batman in The Dark Knight refer to and repeat differently the actions of Christ. It is in identifying this reference point that we find the difference between Nolan's Batman and the superhero genre. For the superhero as the figure beyond the law operates as the exception to it and, as such, enables its completion or fulfilment beyond its limits. In the state of exception or emergency the superhero, out of necessity, goes beyond the law and operates as if it is suspended in order to deal with the crisis and restore the social order. The superhero in the end becomes the exception that determines legality and this is why superhero films are so easily incorporated into conservative post-9/11 ideologies around the need for exceptional measures in the 'war on terror'. Nolan's version of Batman, however, frames a form of exclusion as opposed to simply the sovereign exception discussed above, which occurs through Batman taking the blame for Harvey Dent's actions. It is not simply that Batman is elevated because of his exceptional relation to the law, but he is envied and rejected because of it. ${ }^{94}$

When the Joker threatens the city with death and destruction if Batman does not take off his mask and turn himself in, Dent tells a press conference that they should not give in to his demands. The crowd-cum-mob rejects Batman and demand that he reveal himself. Rachel, Bruce's best friend and one of the few people who knows his secrets rejects him, believing that there would never come a day when he did not need to be Batman. Finally, in the closing scenes of the film, when Batman takes

\footnotetext{
${ }^{90}$ Milbank (2003), p 96.

${ }^{91}$ Milbank (2003), p 99. This is not a pacifist refusal of violence (which in the end, engages in the violent gaze of the onlooker who does nothing about the violence he observes) but rather an identification of the futility of fighting finite potency with finite potency. Rather 'In refusing violence, Christ also exercised a militant opposition to violence.' Milbank (2003), p 100. See also Milbank (2003), chapter 2.

${ }^{92}$ As Milbank notes, 'Jesus only submits to being handed over because he is in himself the very heart of all transition as really loving gift, and thereby able to subvert every betrayal and abandonment.' Milbank (2003), p 99.

${ }^{93}$ Milbank (2003), p 98.

${ }^{94} \mathrm{McGowan}$ pinpoints this form of envy in his analysis of the 'fake Batmen' who want to help. McGowan argues that the problem of the exception itself is that it continues to expand the realms of exceptionality (everyone wants to participate in this exceptional relationship to the law). For McGowan, this is the reason that Batman must become the figure of evil, in order to quell the desire for an exceptional relationship to law. See McGowan (2009), paras 15-16, $47-59$.
} 
the blame for Dent's murders, he is rejected and cast out by the police who will now hunt him down as a criminal and an outlaw. Batman is thus excluded at every level: in terms of his role as protector of Gotham (by the democratic will of the mob), in his personal relationships because of his role as Batman (by Rachel) and finally in his relationship to the law itself (by Gordon and the police). Yet, it is through these exclusions that we see how Batman refuses the heroic and sovereign employing of the exception as a means of justifying his actions. Instead, it is in the process of not being a hero that Batman lays bare the fundamental violent elements of the law and the arbitrary exercise of sovereign power. ${ }^{95}$ In effectively taking the blame for Harvey Dent's murders he puts the law on display revealing its failure to identify, let alone punish, the criminal. Batman becomes the exception via exclusion and rejection, which opens another space outside of the law and its punishment - outside of the exception which is included via its exclusion. This acceptance of the position of exclusion is one that involves a non-resistance to human violence, a non-resistance founded on love or compassion which challenges both the law and its grounding in violence. ${ }^{96}$

It is from this perspective that we can understand Batman's actions not as a form of vigilante retributive justice, but rather as compassionate acts of preventative justice attempts to prevent crimes from being committed and from evil being done, which arise out of a care for both the potential victim and the potential perpetrator. ${ }^{97}$ This compassion is the way to understand Batman's actions in the final confrontation with Harvey at the end of The Dark Knight. When Batman appears on the scene he says 'You don't want to hurt the boy Harvey' (to which Harvey responds, as we noted earlier 'it's not about what I want, it's about what's fair'). In this invocation from Batman there is an attempt not just to defuse the situation but also a compassionate response that recognises that Harvey does not want to engage in this act of violence (killing Gordon's son). Batman is not only interested in saving the city or the boy but also desires to save Harvey as well. ${ }^{98}$ When, after being shot, Batman then lunges at Harvey it is not simply about saving Gordon's son (which he does) but it is also about saving Harvey - both from death but, more importantly, from an

\footnotetext{
${ }^{95}$ The point about not being a hero is made by Alfred earlier in the film. When Harvey initially turns himself in as being the Batman (in an attempt to quell the crowds and draw out the Joker for Batman to take down), Rachel is distraught as to why Bruce did not come forward to set the record straight. Alfred responds by saying '[p]erhaps both Bruce and Mr Dent believe that Batman stands for something more important than the whims of a terrorist, Ms Dawes. Even if everyone hates him for it. That's the sacrifice he's making. He's not being a hero. He's being something more.' Rachel does not seem to understand this point by claiming that Bruce 'letting Harvey take the fall ... is not heroic at all'.

${ }^{96}$ In Batman Begins we see quite specifically Bruce's confrontation and challenge to Ra's Al Ghul is based on compassion (which Ra's criticises him for). This compassion thus becomes foundational for all his actions as Batman. See discussion in Peters (2007).

${ }^{97}$ For a discussion of this type of violence or counter-violence, see Milbank (2003), chapter 2.

${ }^{98}$ Whilst Dent turns to his rage and his now misplaced sense of 'justice as chance' as a way of avenging Rachel's death, Batman is acknowledging both that Rachel's death was not a result of chance but a result of actions that were taken (by Batman, Harvey and Gordon as much as by the Joker) and that Harvey, at a later time would likely regret the action he was about to take to hurt the boy. That is, Rachel's death was a result of their specific decision to act and, as such, they bear the responsibility for those actions - actions that engaged in preventative violence in the sense of the prevention of the commission of violence, rather than the punishment of the criminal: See Milbank (2003), chapter 2, in particular pp 36-43.
} 
action of violence that he would later regret. This action of preventative violence fails in terms of Harvey's death, but succeeds in terms of ensuring that Dent is not the murderer of an innocent little boy. ${ }^{99}$ This is important because, whilst Harvey's other killings were in effect, as we saw above, a dealing of retributive justice beyond the law (killing those who were directly involved in Rachel's death - corrupt cops and mobsters) the killing of Gordon's son would be something else altogether.

The subsequent actions by Batman in taking the blame for Dent's killings, which present a certain moral discomfort, are directly aimed at both saving Dent and at challenging the Joker's accusations of the people of Gotham - that underneath the supposed civility of law and society lies the violence and natural rights of the state of nature; that, given the right circumstances and the deficiency of the law to maintain its monopoly on violence, anybody can revert back to these natural rights. However, Batman comes to understand that the final challenge to the Joker cannot occur at the level of an ever-escalating violent exchange. Rather, the only way to counter the violence of the state of nature is not with more violence but with an active non-resistance to violence. To challenge the Joker's claim requires an act of compassion that does not invoke either the arbitrary justice of the law or the natural rights of the state of nature. Such a non-resistance to violence and to the law opens the possibility for a different conception of law and a different founding of the community - one based not on a self-interested wielding of ultimately violent natural rights, but an underlying faith or trust in the possibility of relationship with others, despite our flaws and tendency towards violence.

This privileging of faith or trust in others is also the important outcome of the 'prisoner's dilemma' scenario on the ferries. In the struggle between Batman and the Joker, the Joker says 'We really should stop this fighting, otherwise we'll miss the fireworks.' Batman's confident response is 'there won't be any fireworks'. Batman maintains a faith in the people of Gotham - both the civilians and the criminals - and later proclaims their failure to blow each other up as a demonstration of their willingness 'to believe in good'. In terms of the scenes that the viewer sees of the people on the ferries themselves, instead of either the criminals or the civilians engaging in the 'calculating' decision of blowing each other up, both groups 'risk it all' by having faith and trust in the other group. On the boat full of civilians, after the 'democratic vote' has come down overwhelmingly in favour of blowing up the other ferry, the captain suddenly realises and points out that they themselves have not been blown up yet - which means that the criminals have not yet taken the action that they are about to take. The risk of the scenario, for both groups, is that in waiting or not blowing up the other that they will themselves be blown up. But that risk is always the risk of trusting in others that our trust may be broken. Whilst our desire for legality is rooted within a need for certainty, and a desire for the protections that the legal system attempts to provides, even those protections and certainty can be undermined because the system is always dependent on individuals who may themselves be corrupted (as presented in Nolan's films - discussed above). In contrast, founding legality and community on trust in one another, even if that trust may be broken, provides the only really way for individuals to come together in solidarity. ${ }^{100}$

\footnotetext{
${ }^{99}$ A point that The Dark Knight Rises misses, with Gordon in his speech (read by Bane) calling Dent a monster who threatened his son.

${ }^{100}$ For the theological framing of this turn to trust as opposed to legality, see Milbank (2010) in particular pp 48-58.
} 
It is this privileging of trust that is the reason that Batman argues that Gotham needs to 'have its faith rewarded' and, in the concluding scene, takes actions that mirror the atoning actions of Christ on the cross. By first preventing Dent from killing Gordon's son and then taking the blame for Dent's murders, Batman both ensures that Dent did not become the monster the Joker was envisioning him to be and also that Gotham City did not see him in this way. Such an action is antithetical to the notion of the hero who, in operating within the role of the exception becomes a law unto himself. ${ }^{101}$ Instead, we find that in the complete non-resistance to the law, in taking the blame and punishment for crimes that he did not commit, the power of the law in both its ability to protect the citizens and condemn the criminals (categories which, in the end, overlap) is broken. It is for this reason that Gordon's concluding voice-over specifically describes Batman as not a hero. Rather, he is 'a silent guardian, a watchful protector ... a Dark Knight'.

\section{Conclusion: 'we don't need another hero'}

Given the biopolitical tensions of the present situation, heightened by the ever increasing series of 'emergencies' and 'crises' that have dominated news headlines since the September-11 attacks in 2001 and reflected by the rise of the superhero on film, Nolan's The Dark Knight Trilogy provides a contrasting message: what we need is not a figure that would embody the exceptional decision of the sovereign which, in the end, is always a decision of life and death. Rather, we need to see that in the capacity to suffer and endure death to the very end, we find a different way of conceiving life that is not based on an economy of death-dealing violence whether authorised or illegitimate, legal or illegal, exceptional or otherwise. The possibility of affirming life itself comes from a recognition of suffering and evil as part of life that must be both endured and responded to. It is only through such an endurance and a response to evil that is not about eradicating the perpetrator so much as compassionately preventing the potential perpetrator from committing an act that they will later regret themselves, that we find a way of affirming life outside of its biopolitical frameworks (not in terms of the 'presumed' natural life outside the law which is always determined by the law, but a life that is in, through and beyond the law itself). It is in this sense that The Dark Knight renders visible both aspects of a particular legal imaginary based on legality and retributive justice, but also opens the possibility of a different response - one that comes in the form of a non-heroic non-resistance of violence, which presumes the possibility of trust as the foundation of community, even at the risk of that trust being broken. This is the importance of the connections between Batman and Christ that I have outlined above - a connection based on the non-heroic as opposed to the heroic (for Christ in no sense fits the tradition of the heroic exception, the Greek cosmology of heroes or the death and re-birth of the Greek gods). Christ represents a divine and human death in a very particular way but also a resurrection that opens the possibility for a new life beyond law - one based in the possibility of faith or trust in each other. If anything, the end-point of The Dark Knight

${ }^{101}$ See McGowan (2009), paras 4-5. 
demonstrates that the solution is not a hero, despite their recent filmic proliferation. That is to say, to repeat in a different context the words of Tina Turner, 'we don't need another hero'. ${ }^{102}$

\section{Acknowledgements}

The author would like to thank and acknowledge Professor William MacNeil, Dr Kieran Tranter, Dr Edwin Bikundo and Rev Dr Andrew Peters for their helpful comments on early drafts of this article, as well as the extremely insightful comments and interventions from the three anonymous reviewers. Thanks also to Dr Cassandra Sharp for the invitation to contribute to this special issue.

\section{References}

Primary legal sources

US Racketeer Influenced and Criminal Organizations (RICO) Act 1970 (Title 18, United States Code, Sections 1961-1968).

New York Penal Code 1967 (NY).

\section{Books, chapters and journal articles}

Giorgio Agamben (1998) Homo Sacer: Sovereign Power and Bare Life, Standford University Press.

Giorgio Agamben (2005) The State of Exception, University of Chicago Press.

Michael Asimow (1996) 'When Lawyers Were Heroes' 30 University of San Francisco Law Review 11.

Jason Bainbridge (2006) 'Lawyers, Justice and the State: The Sliding Signifier of Law in Popular Culture' 15(1) Griffith Law Review 153-176.

Jason Bainbridge (2007) "“This Is the Authority. This Planet Is under Our Protection" - An Exegesis of Superheroes' Interrogations of Law'3(3) Law, Culture and the Humanities 455-476.

Jason Bainbridge (2012) 'Spider-Man, The Question and the Meta-Zone: Exception, Objectivism and the Comics of Steve Ditko' 16 Law Text Culture 217.

Jason Bainbridge (2015) "The Call to Do Justice": Superheroes, Sovereigns and the State During Wartime' International Journal for the Semiotics of Law (published online). doi:10. 1007/s11196-015-9424-y.

Adam Barkman (2013) 'Superman: From Anti-Christ to Christ-Type' in Mark D White (ed) Superman and Philosophy: What Would the Man of Steel Do?, John Wiley \& Sons.

Charles K Bellinger (2009) 'The Joker Is Satan, and So Are We: Girard and the Dark Knight' 13 (1) Journals of Religion and Film 5.

Walter Benjamin (1986) 'Critique of Violence' in Peter Demetz (ed) Reflections: Essays, Aphorisms, Autobiographical Writings, translated by Edmund Jephcott, Schoken Books.

Benjamin L Berger (2008) 'On the Book of Job, Justice and The Precariousness of the Criminal Law' 4 Law Culture and the Humanities 98-118.

Joseph Campbell (1973) The Hero with a Thousand Faces (3rd ed), Princeton University Press. Hans-Christian Christiansen (2000) 'Comics and Film: A Narrative Perspective' in A Magnussen and HC Christiansen (eds) Comics \& Culture: Analytical and Theoretical Approaches to Comics, Museum Tusculanum Press.

Norman Cohn (2001) Cosmos, Chaos, and the World to Come: The Ancient Roots of Apocalyptic Faith, Yale University Press.

${ }^{102}$ Tina Turner 'We Don't Need Another Hero (Thunderdome)' by Terry Britten and Graham Lyle., Mad Max: Beyond The Thunderdome, Original Motion Picture Soundtrack, Capitol Records, (1985). 
Robert M Cover (1986) 'Violence and the Word' 95 The Yale Law Journal 1601.

Jacques Derrida (1992) 'Force of Law: The "Mystical Foundation of Authority"' in Drucilla Cornell et al (eds) Deconstruction and the Possibility of Justice, Routledge.

Peter Fitzpatrick (2001) Modernism and the Grounds of Law, Cambridge University Press.

Vincent M Gaine (2011) 'Genre and Super-Heroism: Batman in the New Millenium' pp 111128 in RJ Gray and B Kaklamanidou (eds) The 21st Century Superhero: Essays on Gender, Genre and Globalization in Film, McFarland \& Company.

Thomas Giddens (2015) 'Navigating the Looking Glass: Severing the Lawyer's Head in Arkham Asylum' 24(3) Griffith Law Review.

Richard J Gray and Betty Kaklamanidou (eds) (2011) The 21st Century Superhero: Essays on Gender, Genre and Globalization in Film, McFarland \& Company.

Thomas Hobbes (1952) 'Leviathan' in Robert Maynard Hutchins (ed), Great Books of the Western World Volume 23: Machiavelli and Hobbes, Encyclopaedia Britannica.

John Ip (2011) 'The Dark Knight's War on Terrorism' 9(1) Ohio State Journal of Criminal Law 209.

Renee Jeffery (2008) Evil and International Relations: Human Suffering in an Age of Terror, Palgrave Macmillian.

Vilja Johnson (2014) “'It's What You Do That Defines You”: Christopher Nolan's Batman as Moral Philosopher' 47 The Journal of Popular Culture 952-967.

Orit Kamir (2005) 'Anatomy of Hollywood's Hero-Lawyer: A Law and Film Study of the Wes Honor-Based Values and Gender Politics Underlying Anatomy of a Murder' 35 Studies in Law, Politics and Society 67-105.

Orit Kamir (2009) 'Michael Clayton: Hollywood's Contemporary Hero-Lawyer: Beyond 'Outsider Within' and 'Insider Without” 42 Suffolk University Law Review 829.

Immanuel Kant (1996) Groundwork of the Metaphysic of Morals in Practical Philosophy, translated and edited by Mary J Gregor, Cambridge University Press.

Immanuel Kant (1998) Religion within the Boundaries of Mere Reason and Other Writings, in Allen Wood and George di Giovanni, Cambridge University Press.

Jacques Lacan (1989) 'Kant with Sade' 51 October 55.

John Lawrence, and Robert Jewett (2002) The Myth of the American Superhero, William B Eerdman Publishing Co.

William P MacNeil (2007) Lex Populi: The Jurisprudence of Popular Culture, Stanford University Press.

William P MacNeil (2012) Novel Judgements: Legal Theory as Fiction, Routledge.

Desmond Manderson (2011) 'Trust Us Justice: 24, Popular Culture, and the Law' in A Sarat (ed) Imagining Legality: Where Law Meets Popular Culture, The University of Alabama Press.

Michael Marano (2008) 'Ra's Al Ghul: Father Figure as Terrorist' in D O'Neil (ed) Batman Unauthorised: Vigilantes, Jokers, and Heroes in Gotham City, BenBella Books.

Todd McGowan (2009) 'The Exceptional Darkness of The Dark Knight' Jump Cut 51, Spring 2009.

Todd McGowan (2012) The Fictional Christopher Nolan, University of Texas Press.

Mervi Miettinen (2011) 'Representing the State of Exception: Power, Utopia, Visuality and Narrative in Superhero Comics' in M Stocchetti and K Kukkonen (eds) Images in Use: Towards the Critical Analysis of Visual Communication, John Benjamins Publishing Company.

John Milbank (2003) Being Reconciled: Ontology and Pardon, Routledge.

John Milbank (2010) 'Paul Against Biopolitics' in J Milbank, S Žižek and C Davis (eds) Paul's New Moment: Continental Philosophy and the Future of Christian Theology, Brazos Press.

Dale Mitchell (2015) 'Paradoxes and Patriarchy: A Legal Reading of She-Hulk' 24(3) Griffith Law Review.

Christine Muller (2011) 'Power, Choice and September 11 in The Dark Knight' in Richard J Gray and Betty Kaklamanidou (eds) The 21st Century Superhero: Essays on Gender, Genre and Globalization in Film, McFarland \& Company.

Pramod K Nayar (2006) Reading Culture: Theory, Praxis, Politics, Sage. 
Michael Nichols (2011) "II Think You and I Are Destined to Do This Forever": A Reading of the Batman/Joker Comic and Film Tradition Through the Combat Myth' 23(2) Journal of Religion and Popular Culture 236.

Adolph Nissen (1877) Das Iustitium: Eine Studie aus der romischen Rectsgeschichte, Gebhardt.

Timothy D Peters (2007) 'Unbalancing Justice: Overcoming the Limits of the Law in Batman Begins' 16(1) Griffith Law Review 247.

Timothy D Peters (2012) 'Comic Book Mythology: Shyamalan's Unbreakable and the Grounding of Good in Evil' 16 Law Text Culture 243.

Timothy D Peters (2014) 'Reading the Law Made Strange: A Theological Jurisprudence of Popular Culture' PhD Thesis, Griffith Law School, Griffith University.

Timothy D Peters (2016) 'Reading the Law Made Strange: Cultural Legal Studies, Theology and Speculative Fiction' in Cassandra Sharp and Marett Leiboff (eds) Cultural Legal Studies: Law's Popular Cultures and the Metamorphosis of Law, Routledge.

Nickie D Phillips (2010) 'The Dark Knight: Constructing Images of Good vs. Evil in an Age of Anxiety' in M Deflem (ed) Popular Culture, Crime and Social Control (Sociology of Crime, Law and Deviance Volume 14), Emerald Group Publishing Limited.

Dennis A Rendleman (2009) 'Two Faces of Criminal Prosecution: Harvey Dent, Mike Nifong, Craig Watkin's' 9 The Journal of the Institute of Justice \& International Studies 171.

Richard Reynolds (1992) Super Heroes: Modern Mythology, University Press of Mississippi.

Bradford W Reyns and Billy Henson (2010) 'Superhero Justice: The Depiction of Crime and Justice in Modern-Age Comic Books and Graphic Novels' 14 Sociology of Crime, Law and Deviance 45.

C. K. Robertson (2005) 'The True Übermensch: Batman as Humanistic Myth' in BJ Oropeza (ed) The Gospel According to Superheroes: Religion and Popular Culture, Peter Lang.

Ken Schenck (2005) 'Superman: A Popular Culture Messiah' in BJ Oropeza (ed) The Gospel According to Superheroes: Religion and Popular Culture, Peter Lang.

Johannes Schlegel and Frank Habermann (2011) "You Took My Advice about Theatricality a Bit ... Litearlly": Theatricality and Cybernetics of Good and Evil in Batman Begins, The Dark Knight, Spider-Man, and X-Men' in RJ Gray and B Kaklamanidou (eds) The 21st Century Superhero: Essays on Gender, Genre and Globalization in Film, McFarland \& Company.

Carl Schmitt (2005) Political Theology: Four Chapters on the Concept of Sovereignty, The University of Chicago Press.

Carl Schmitt (2014) Dictatorship, Polity Press.

Cassandra Sharp (2011) 'Religion and Justice: Atonement as an Element of Justice in Both Western Law and Christian Thought' in $\mathrm{R}$ Mohr and N Hosen (eds) Law and Religion in Public Life: The Contemporary Debate, Routledge.

Cassandra Sharp (2012) "'Riddle Me This ... ?" Would the World Need Superheroes if the Law Could Actually Deliver "Justice"?' 16 Law Text Culture 353.

Anthony Peter Spanakos (2011) 'Exceptional Recognition: The U.S. Global Dimension in The Incredible Hulk, Iron Man and Avatar' in RJ Gray and B Kaklamanidou (eds) The 21st Century Superhero: Essays on Gender, Genre and Globalization in Film, McFarland \& Company.

Andrew E Taslitz (2004) 'Daredevil and the Death Penalty' 1 Ohio State Journal of Criminal Law 699.

Shaun Trent (2009) 'How America Learned to Stop Worrying and Cynically ENJOY! The Post9/11 Superhero Zeitgeist' 6(1) Communication and Critical/Cultural Studies 103.

Scott Vollum and Cary D Adkinson (2003) 'The Portrayal of Crime and Justice in the Comic Book Superhero Mythos' 10(2) Journal of Criminal Justice and Popular Culture 96.

Slavoj Žižek (2010) Living in the End Times, Verso.

Slavoj Žižek (2012a) 'The People's Republic of Gotham', New Statesman, 24 August 2012.

Alenka Zupančič (2000) Ethics of the Real: Kant, Lacan, Verso.

\section{Films}

The Amazing Spider-Man (2012) directed by Marc Webb, Columbia Pictures.

The Amazing Spider-Man 2 (2014) directed by Marc Webb, Marvel Enterprises.

Avengers: Age of Ultron (2015) directed by Joss Whedon, Marvel Studios. 
Batman (1989) directed by Tim Burton, Warner Brothers Pictures.

Batman Begins (2005) directed by Christopher Nolan, Warner Brothers Pictures.

Batman v Superman: Dawn of Justice (forthcoming) directed by Zack Snyder, DC Entertainment.

Captain America (2011) directed by Joe Johnston, Paramount Pictures.

Captain America: Winter Soldier (2014) directed by Anthony Russo and Joe Russo, Marvel Entertainment.

The Dark Knight (2008) directed by Christopher Nolan, Warner Brothers Pictures.

The Dark Knight Rises (2012) directed by Christopher Nolan, Warner Brothers Pictures.

Fort Apache (1948) directed by John Ford, Argosy Pictures.

Guardians of the Galaxy (2014) directed by James Gunn, Marvel Studios.

Iron Man 2 (2010) directed by Jon Favreau, Paramount Pictures.

Iron Man 3 (2013) directed by Shane Black, Marvel Studios.

Man of Steel (2013) directed by Zack Snyder, Warner Brothers Pictures.

The Man Who Shot Liberty Valence (1962) directed by John Ford, Paramount Pictures.

Marvel's The Avengers (2012) directed by Joss Whedon, Walt Disney Studios Motion Pictures.

Thor (2011) directed by Kenneth Branagh, Paramount Pictures.

Thor: The Dark World (2013) directed by Alan Taylor, Marvel Studios.

\section{Comic books and graphic novels}

Frank Miller, Klaus Janson and Lynn Varley (1986) The Dark Knight Returns, DC Comics.

Alan Moore, Brian Bolland and Richard Starkings (1988) Batman: The Killing Joke, DC Comics.

\section{Websites and blogs}

Cogitamus (2008) 'The Dark Knight and international politics'.

Slavoj Žižek (2012b) 'Dictatorship of the Proletariat in Gotham City'.

\section{Newspaper and magazine articles}

Spencer Ackerman (2008) 'Batman's 'Dark Knight' Reflects Cheney Policy', The Washington Independent, 21 July 2008.

Joe Allen (2008) 'Batman's war on terror', Counterpunch, 2 August 2008.

Andrew Bolt (2008) 'Batman Bush true dark Knight', Herald Sun, 30 July 2008.

Richard Crouse (2009) 'Dark Knight has Reviewer Seeking New Words for Awesome', CTV, 18 July 2009.

Andrew Klavan (2008) 'What Bush and Batman Have in Common', Wall Street Journal, 25 July 2008.

NY Times Editorial Board (2008) 'Batman and the War on Terror', The New York Times, 21 July 2008.

Tyler O’Neil (2012) 'Dark Knight and Occupy Wall Street: The Humble Rise', Hillsdale Natural Law Review, 21 July 2012.

Christopher Orr (2008) 'Batman as Bush Ctd', The New Republic, 17 July 2008.

Matthew Yglesias (2008) 'Dark Knight Politics', The Atlantic, 24 July 2008.

\section{Songs, music and other media}

Tina Turner (1985) 'We Don’t Need Another Hero (Thunderdome)' by Terry Britten and Graham Lyle, Mad Max: Beyond The Thunderdome, Original Motion Picture Soundtrack, Capitol Records. 